\title{
Suitable economic models for Open Educational Resources initiative in aquaculture higher education
}

\author{
Alexandra Pounds ${ }^{1}$ (D) John Bostock ${ }^{1}$ \\ Received: 10 September 2018 / Accepted: 30 May 2019 /Published online: 6 June 2019 \\ (C) The Author(s) 2019
}

\begin{abstract}
Many initiatives are developing Open Educational Resources (OERs) in a variety of sectors because they have the potential to increase access to education and knowledge. Investment is a limiting factor for many of these initiatives. Future OER initiatives in the aquaculture community, such as the development of the AquaCase 3.0 website, will need to address this limitation by establishing a sustainable financial model. One way to do this is by relying on volunteer content creation. This study examined whether educators and students in the aquaculture community already contribute their materials, and if they would be willing to voluntarily contribute their materials in the future. Responses to online questionnaires of students and educators in the aquaculture community suggested that, although respondents currently have low creation to usage ratios, respondents would be willing to contribute their materials voluntarily for altruistic and promotional reasons, which would reduce the costs of such an initiative. In order for this to happen, institutions must support Open Resource Practices (ORPs) among their educator and student base through revised copyright policies. Governments may wish to incentivize institutions to encourage OER contribution by providing funding based on OER development.
\end{abstract}

Keywords Aquaculture · Aquatic resources management · Cost · Economic models · Funding · Open Educational Resources · Rural development · Training

\section{Abbreviations}

$\begin{array}{ll}\text { CC } & \text { Creative Commons (Licensing) } \\ \text { FAO } & \text { Food and Agriculture Organization } \\ \text { MIT OCW } & \text { Massachusetts Institute of Technology's OpenCourseWare } \\ \text { OA } & \text { Open Access } \\ \text { OER } & \text { Online Education Resource }\end{array}$

Alexandra Pounds alexandrapounds@gmail.com 


\section{ORP Online Resource Practice}

SARNISSA Sustainable Aquaculture Research Network in Sub-Sahara Africa

UNESCO United Nations Educational Scientific and Cultural Organization

\section{Introduction}

Open Educational Resources (OERs) are free, modifiable, and distributable educational materials, as defined by UNESCO (Carson 2006). OER materials have the potential to increase access to education in impoverished and remote communities, which is particularly relevant for a substantial portion of the aquaculture community. Education initiatives, such as the EU Horizon 2020 project "EURASTIP" (EU 2017), are investigating if OERs have a role in achieving their objectives. These types of projects, which develop OERs, are on the rise (Atkins et al. 2007) and are different than the Open Access (OA) movement, which generally tends to produce research materials or literature rather teaching resources.

Investment for OER development, contribution, and ongoing sustainability is the first concern for potential developers (Dholakia et al. 2006). While OERs, by definition, are free for users, development of OERs and repositories has often required a significant investment to cover the costs of content creation, platform development, and ongoing maintenance, which are largely reliant on human resources and workflow processes (Wiley 2007). Chapman Alliance estimated that one e-course requires $\$ 10,000$ to $\$ 51,000$ and 79 to $490 \mathrm{~h}$, depending on the type of material and level of interaction (Chapman 2010). Massachusetts Institute of Technology's OpenCourseWare (MIT OCW) has a \$4.3 million annual budget, \$2.1 million of which is allocated to staff (Wiley 2007).

OERs and repositories can exist under several different economic funding models, as shown in Table 1.

Some models depend on material-driven top-down and developed solely by the institution in a producer-consumer model, like MIT OCW, whereas others depend on a grassroots collective knowledge contribution in a co-producer model, like Rice University's Connexions (Dholakia et al. 2006; Herrera 2010). The producer-consumer model is more expensive than the co-producer model, as the producer-consumer model relies more heavily on the institution or donors rather than the users for organization and development (Herrera 2010). Most donor-driven activities collapse once donor support ends, leaving initiatives under the donations model highly dependent on continued donor support (Kanwar et al. 2010). This model does not secure long-term sustainability. As such, it may be useful to integrate OER initiatives with community of practice initiatives, where coalitions of people who share a craft or profession come together to share knowledge with each other (Wenger 1998).

Several authors have found that a cost-benefit model that reduces costs is critical to the sustainability of the projects (Herrera 2010; Downes 2007; Wiley 2007). The first way to reduce costs is to increase reach and extend the lifespan. This leads to an economy of scale, which reduces costs via amortizations (Butcher and Hoosen 2012; Camilleri et al. 2012). As the cost per user depends on reach, "the success of OER mainly depends on how easily they can be adapted and modified to the re-users' context" (Pawlowski and Bick 2012). Thus, high levels of accessibility and well-developed Open Resource Practices (ORPs) are critical for reducing amortized cost. 
Table 1 Categorization of various OER project financial models (Downes 2007; Collins and Levy 2013; Dholakia et al. 2006)

\begin{tabular}{|c|c|c|c|}
\hline Source & Model type & Funding source & Example \\
\hline $\begin{array}{l}\text { (Collins and Levy } \\
\text { 2013; Downes } \\
\text { 2007) }\end{array}$ & $\begin{array}{l}\text { Endowments } \\
\text { model }\end{array}$ & $\begin{array}{l}\text { Interest earned from base funding } \\
\text { investment sustains the project. }\end{array}$ & $\begin{array}{l}\text { Stanford Encyclopaedia } \\
\text { of Philosophy }\end{array}$ \\
\hline $\begin{array}{l}\text { (Collins and Levy } \\
\text { 2013; Dholakia } \\
\text { et al. 2006; Downes } \\
\text { 2007) }\end{array}$ & $\begin{array}{l}\text { Memberships } \\
\text { model }\end{array}$ & $\begin{array}{l}\text { Coalition of organizations contribute } \\
\text { funding for the project, either one-time } \\
\text { or on a subscription basis. }\end{array}$ & $\begin{array}{l}\text { Sakai Educational } \\
\text { Partners Program; } \\
\text { AquaCase } 3.0\end{array}$ \\
\hline $\begin{array}{l}\text { (Collins and Levy } \\
\text { 2013; Downes } \\
\text { 2007) }\end{array}$ & $\begin{array}{l}\text { Donations } \\
\text { model }\end{array}$ & $\begin{array}{l}\text { Private or community donations managed } \\
\text { by a non-profit fund the project. }\end{array}$ & Wikipedia \\
\hline $\begin{array}{l}\text { (Collins and Levy } \\
\text { 2013; Dholakia } \\
\text { et al. 2006; Downes } \\
\text { 2007) }\end{array}$ & $\begin{array}{l}\text { Conversions } \\
\text { model }\end{array}$ & $\begin{array}{l}\text { Freebies convert consumers into paying } \\
\text { customers. }\end{array}$ & LAMS \\
\hline (Downes 2007) & $\begin{array}{l}\text { Contributor-pay } \\
\text { model }\end{array}$ & $\begin{array}{l}\text { Contributors are responsible for } \\
\text { maintenance and updates to their } \\
\text { OERs, placing economic responsibility } \\
\text { on the contributor. }\end{array}$ & \\
\hline $\begin{array}{l}\text { (Collins and Levy } \\
\text { 2013; Downes } \\
\text { 2007) }\end{array}$ & $\begin{array}{l}\text { Sponsorship } \\
\text { model }\end{array}$ & Income is earned from advertisements. & $\begin{array}{l}\text { Stanford on iTunes } \\
\text { Project }\end{array}$ \\
\hline (Downes 2007) & $\begin{array}{l}\text { Institution } \\
\text { model }\end{array}$ & Associated institution funds the project. & MIT OCW \\
\hline (Downes 2007) & $\begin{array}{l}\text { Government } \\
\text { model }\end{array}$ & $\begin{array}{l}\text { Associated government body funds the } \\
\text { project. }\end{array}$ & $\begin{array}{l}\text { Canada's SchoolNet } \\
\text { Project }\end{array}$ \\
\hline (Downes 2007) & $\begin{array}{l}\text { Partnerships and } \\
\text { exchanges }\end{array}$ & $\begin{array}{l}\text { No funding or income. This model relies } \\
\text { on exchange of resources rather than } \\
\text { money. }\end{array}$ & $\begin{array}{l}\text { International } \\
\text { Fellowships at the } \\
\text { Open University }\end{array}$ \\
\hline (Dholakia et al. 2006) & $\begin{array}{l}\text { Substitution } \\
\text { model }\end{array}$ & $\begin{array}{l}\text { Funds for OER creation are reallocated } \\
\text { from budgets for other technology } \\
\text { software, such as virtual learning } \\
\text { environments or course management } \\
\text { systems. }\end{array}$ & $\begin{array}{l}\text { University of California } \\
\text { at Merced's } \\
\text { Connexions } \\
\text { contributions }\end{array}$ \\
\hline
\end{tabular}

Reducing the overall funding requirements is also important to make projects' goals realistically attainable. Downes (2007) goes as far as to recommend that "the most intriguing support possibility... is to reduce the cost of the [OERs] projects so drastically that there is little or nothing left to fund." This is achievable in various ways:

\section{Use of volunteers}

As the vast majority of funds are spent on staff, involving volunteers in both contribution and maintenance can dramatically reduce costs (Downes 2007; Wiley 2007). Initiatives in other sectors have used this tactic successfully: MERLOT II project accepts volunteer contributions, which are then peer-reviewed (Downes 2007) and Rice University's Connexions project has a $\$ 0$ budget by relying entirely on volunteer OER contribution and free software tools available from Rhaptos.org (Wiley 2007; Dholakia et al. 2006). The ICT Professional Development Strategy for Teachers in Guyana significantly reduced their budget by uploading pre-existing educational materials to repositories rather than creating new materials from scratch (Butcher and Hoosen 2012). 
Creation of cheaper content formats

Using OERs in text, audio, and visual format is easier and cheaper to produce than simulation and interactive content (Wiley 2007). OER developers should take advantage of using these cheaper medias, as the effectiveness of learning is a function of material design and quality, rather than type of material or medium (Wiley 2007).

Teacher-centered materials are generally simpler and less robust than learner-centered material (Wiley 2007). Learner-centered materials assume little to no pre-existing knowledge in the subject and must provide extensive notes and explanations of content, whereas teachercentered materials may simply provide an outline or sequencing of topics under the assumption that the teacher is already an expert in the subject area (Wiley 2007). Materials for teachers are clearly easier to create, and may be useful for other educators preparing learner-centered material; however, un-adapted, teacher-centered material will be less useful as the demand for OERs from students and lifelong learners increases. While the original creation of learnercentered materials is more expensive, learner-centered materials have the capacity to influence more learners, thus reducing costs through amortization.

Using pre-existing tools, popular software, and freeware

Using free, pre-existing tools that are already widely understood and utilized can further reduce costs. For OER creation and modification, these tools include word processors or collaborative editing programs like Google Docs, whose use should be encouraged through ORPs, rather than PDF files that are difficult to edit (Atkins, et al 2019).

Using the Creative Commons (CC) free online license generator can reduce legal costs. The CC web application allows OER creators to easily customize a CC copyright license for their OER materials, outlining how the OER may be used (Atkins, et al 2007).

Repositories can also use pre-existing technology to establish an open peer-review system. Pre-existing social networking technology could easily be adapted to a repository for the peerreview process (Pawlowski and Bick 2012; Kawachi 2014). OER materials could be "liked," rated, and receive feedback similar to social media systems like Facebook, allowing contribution to be learner-driven as well as educator-driven while preserving transparency around quality. This can result in collective intelligence and crowdsourcing, with quality-assurance managed by the social network-driven open peer-review. One experiment by Nature Magazine found that this type of open peer-review system was not effective because the number and quality of review comments were poor (Atkins, et al 2007); however, increasing development of open resource practices could increase the success rate of such systems (Ehlers 2011).

Unlike many other supporting technologies, translation technology services are limited and will require further development to support OERs and ORPs. Translation services, like Google Translator, offer huge potential to assist in international dissemination of materials and are being developed; however, the translations often require extensive proofreading and editing. Further development of this technology is required.

\section{Re-licensing pre-existing free material}

Free material exists and already has an impact on the sector, such as FAO's database and publications. In addition, collective knowledge-base systems are being developed and utilized, such as SARNISSA (Sustainable Aquaculture Research Network in Sub-Sahara Africa). 
Reports and other outputs from these pre-existing databases could be published under a CC license and re-oriented to contribute to OER development. CC licensing could allow small extractions from longer reports to be repurposed into open formats. Metadata and strategic keywords that provide access through general search engines could even eliminate the need for a centralized repository, thus reducing central operating and maintenance costs.

With these recommendations, establishing an OER initiative for the aquaculture community seems to be best served under a grassroots volunteer contribution model, with funding allocated towards platform design, ongoing maintenance, and ORP development. As the success of such a project would rely on volunteer contributions, this study explored whether the aquaculture higher education community would be willing to support an OER initiative by volunteering their materials, and what would motivate them to do so.

\section{Methods}

Un-proctored, open-mode online questionnaires hosted by Google Forms were distributed to aquaculture educators and students via social media and email networks using a convenience sampling method. The questionnaires were designed based on methods and recommendations described by Callegaro et al. (2015). The questionnaires were tested using cognitive testing methods described by Collins (2003) and Krosnick (1999). They were open for approximately 6 weeks.

These questionnaires were part of a larger project at the University of Stirling's Institute of Aquaculture and were designed to collect quantitative and qualitative data on perspectives on OERs and online resources within the aquaculture community (Pounds 2017). Part of the survey asked about contribution habits of respondents as well as their willingness to contribute. Respondents were asked if they use online materials for learning and educating purposes, if they had ever uploaded their own materials online for others to use, and, if they would be willing to upload their own materials, how others could use them. Respondents were also given open questions to collect qualitative data explaining their answers. Statistical analysis included confidence intervals using Clopper-Pearson methods and chi-squared tests with Yates continuity correction. Statistical analysis was performed with RStudio.

The results were affected by several biases. Firstly, the questionnaires were not accessible to all students and educators in the aquaculture, particularly those without social media or direct connection to higher education institutions, due to the convenience sampling methods. Secondly, although confidentiality should encourage participants to answer honestly, results may be biased towards altruistic tendencies, as questionnaire respondents usually over-report altruistic characteristics within themselves (Krosnick 1999). Further, the results were limited by several biases intrinsic to online questionnaires and to the distribution methods used, including acquiescence and self-selection bias.

\section{Results}

Most respondents were full-time postgraduate students or educators in aquaculture topics, as shown in Table 2. "Other subject areas" included capture fisheries, marine biology, biotechnology, ecology and environmental management, and others related to aquatic resources management. For educators, $62 \%$ had their lesson appraised by their peers and taught students 
Table 2 Demographics of student and educator respondents

\begin{tabular}{lll}
\hline & Students & Educators \\
\hline Total number of respondents & 109 & 77 \\
Postgraduate & 82 & 47 \\
Undergraduate & 16 & 36 \\
CPD & 7 & 13 \\
Vocational & 0 & 5 \\
Aquaculture & 84 & 45 \\
Capture fisheries & 6 & 6 \\
Both & 16 & 5 \\
Other subject areas & 2 & 20 \\
Full-time & 90 & $\mathrm{n} / \mathrm{a}$ \\
Part-time & 10 & $\mathrm{n} / \mathrm{a}$ \\
Not formally enrolled & 7 & $\mathrm{n} / \mathrm{a}$ \\
Have had lessons appraised by peers & $\mathrm{n} / \mathrm{a}$ & 48 \\
Have not had lessons appraised by peers & $\mathrm{n} / \mathrm{a}$ & 28 \\
\hline
\end{tabular}

from a variety of regions. Educator respondents had a wide variety of levels of teaching experiences.

While $96-100 \%$ of both students and educators reported that they used online materials to study or prepare for lessons, only $35-56 \%$ of students and $0-33 \%$ of educators uploaded their own materials for others to use, depending on region. The contribution to usage ratio for all students was 0.42 , whereas the ratio was 0.13 for educators. Students have uploaded their work significantly more than educators ( $p$ value $=1.529 \mathrm{e}^{-5}$ with Yates continuity correction). Confidence intervals showed that the difference between upload and usage rates was only statistically significant in Europe and Asia for both students and educators. Other regions did not have a large enough sample size for statistically significant results. There were no significant differences between upload and usage rates between regions.

Figure 1 shows what students and educators believe would motivate them to upload and share their materials. Respondents were able to select to more than one answer.

Overall, more respondents were willing to share than not share, regardless of drivers. Students were most motivated by altruism, whereas educators were most motivated by encouragement

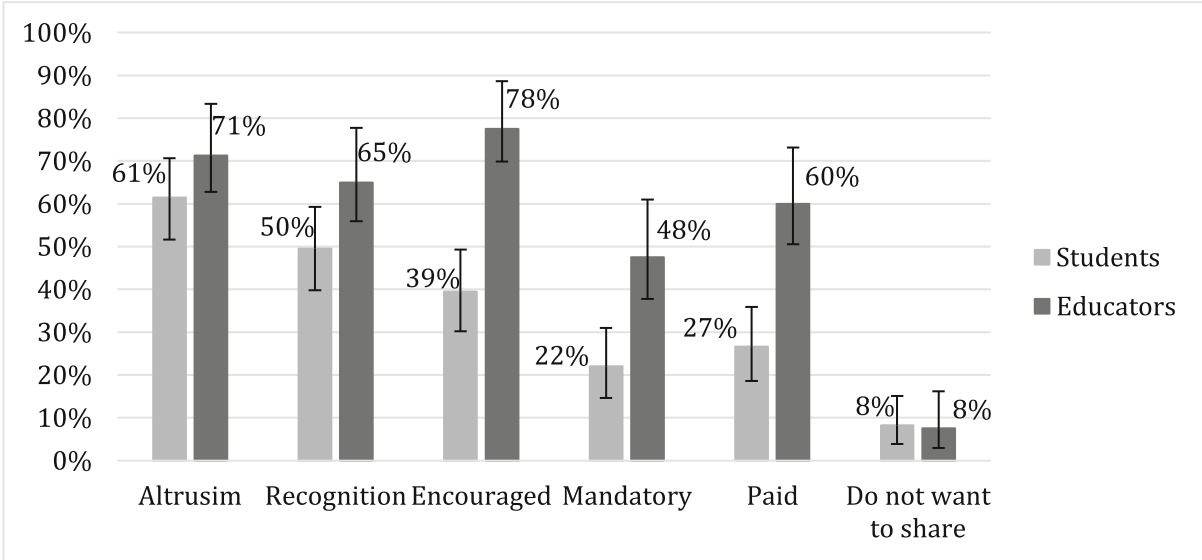

Fig. 1 Percentage of students and educators who would be willing to upload their materials as OERs under different drivers 
from their superiors as well as altruism. Educator respondents were significantly more motivated than student respondents for the drivers "encouraged," "mandatory," and "paid."

As shown in Fig. 2, educator respondents were significantly more willing for their work to be used non-commercially than commercially: educators that did not require commercial benefits significantly outnumbered those that did. Significantly, educators required acknowledgment that they were the original authors. There were no significant differences between whether or not educators were willing for their work to be modified or distributed: educators seemed torn between whether they would be willing for their work to be modified.

\section{Discussion}

\section{Current usage and upload rates}

Student respondents upload their work significantly more than educators. This could be attributed to theories suggesting that students are more comfortable and ICT literate than educators; however, some studies have showed that generational differences have no significant effect on ICT literacy (Lai and Hong 2014; Guo et al. 2008). The more likely reason is that, in contrast to students, teachers depend on their materials for income and are subject to their institutions copyright policies, which may prevent uploading. Some educators are unwilling to donate their material due to competition, pedagogical and monetary reasons, or institutional barriers. Many educators, who already have developed educational materials that could be relicensed as OERs, are prohibited from doing so because their employing institution owns the copyright license. In addition, these expert educators will usually have full-time employment and will be unable to volunteer time for contribution. Although data from this survey did not suggest skepticism, educators may be aware of prior OER projects that have failed and may be hesitant to invest their own resources in projects with what they perceive as a low success rate. This may also be a limitation of the survey, where the meaning of "upload" might have been unclear, leading to confused response.

Without expert contribution, OER repositories risk relying on lower quality materials from volunteers who may have time but not expertise. Furthermore, equal contribution of students

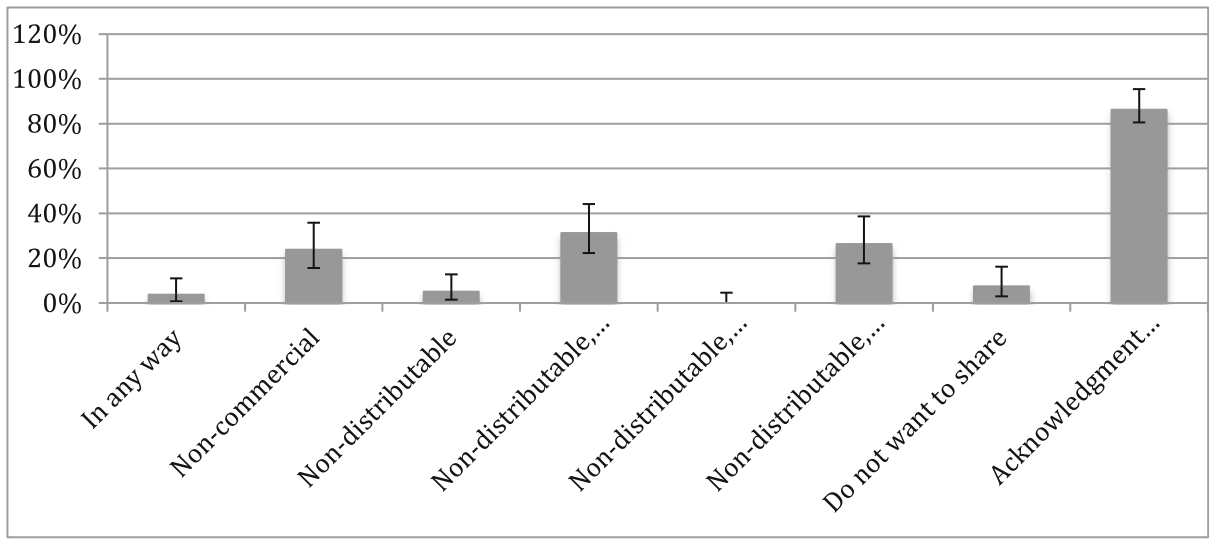

Fig. 2 Creative Commons license condition preferences under which educators would want their shared work to be licensed 
and educators is paramount to the success of "Students as Partners" educational projects, where the importance of reciprocity and inclusivity between students and educators has been identified across literature (Mercer-Mapstone et al. 2017). ORPs should be designed to boost contribution rates and usage rates of both students and educators for healthy adoption.

ORPs that support contribution rates and develop educators' skills at searching for, identifying, and adapting OERs would boost overall contribution rates and usage rates, supporting a healthy creation to usage ratio. Educators skills in using these materials need to be developed through ORPs and formal trainings provided by their institutions. These trainings could include supporting documents for educators, such as strategic lists and keywords, to enable effective searches.

\section{Current creation to usage ratio}

Athabasca University found that the ratio of creation to usage could be a key performance indicator for OER health (McKerlich et al. 2013). They suggest that a ratio of slightly less than one could be an indicator of healthy adoption of OERs, although further research is required to determine the optimal ratio (McKerlich et al. 2013). As the student and educator respondents reported a contribution to use ratio that is quite small in comparison with Athabasca University $(\sim 0.72)$, this may indicate that there is not a healthy adoption of OER yet in the aquatic resources management community. To improve this metric, contribution rates would need to increase, as usage rates are already high.

For this to happen, institutions need to change their copyright policies and develop institutional ORPs to support educators releasing their materials under creative commons licenses (Pawslowski and Bick 2012). Currently, the higher education climate is slowly shifting towards greater accountability in teaching, where teaching portfolios, which document teaching credentials and development, are increasingly popular to evaluate educators' performance (Wiley 2007). Requiring OERs as part of the tenure process, evidenced through portfolios, is an opportunity to shift the entire community's culture towards embracing OERs and reducing barriers to contributors of all motivations (Wiley 2007).

For enhanced collaboration across institutions, ORPs should be implemented at the regional and national levels. Governments could encourage institutions to change their copyright policies and develop OERs and ORPs by offering increased funding to institutions with high levels of contribution (Power 2000). OERs could be an inclusive solution, where profits could be conserved while increasing accessibility to education. Governments already either directly or indirectly fund much of the non-OER material production in education. Shifting some of those funds to prioritize OERs would not increase expenditure and possibly lead to savings due to increased reach, although part of that reach may extend largely to ex-national participants who do not pay taxes and do not contribute to funding. Regardless, governments may be the most likely economic supporters of the OER movement moving forward for administration or technology costs that are unable to be entirely supported through volunteer contributions.

\section{Motivations for contribution}

Despite currently low levels of contribution rates, the majority of both student and educator answers indicated that they were willing to voluntarily share their materials, as in other studies such as the one at Athabasca University (McKerlich et al. 2013). 
Altruistic drivers, recognition and encouragement, motivated both students and educators more so than financial rewards. Student comments confirmed this: 32 student respondents commented that their motivation was related to "sharing" or "helping others." Similarly, contributors to the Connexion's project were driven to contribute due to recognition and personal brand exposure (Dholakia et al. 2006). For example, Catherine "Kitty" SchmidtJones is a private music teacher who prolifically uploads OER materials to the The Connexions project and has over 600,000 page views of her materials in January 2006 alone (Dholakia et al. 2006). Like Schmidt-Jones, certain select individuals seeking brand development may become the champions of an initiative via their mass contributions, as very few people have the motivation, time, and freedom to contribute substantially.

It was not expected that neither students nor educators would be most motivated if contributing was mandatory; this may have been caused by confusion that more than one answer could be checked, or due to satisficing, as this question was towards the end of the questionnaire.

While altruistic motivators were common for both students and educators, barriers to contribution differed between the two groups. For students, intellectual property and plagiarism were mentioned as a concern in the comments; however, lack of confidence in the quality of their own materials and lack of awareness that it might be useful were more commonly suggested as barriers to contribution. For example, one student commented, "I don't think I am qualified to upload or the material I am going to upload is useful", while another commented, "I wouldn't know where to upload them and would be worried about plagiarism." None of the comments reflected that lack of payment was a barrier, as suggested by the quantitative data.

Sharing between students increases the likelihood that institutions may experience difficulties distinguishing between intra-class plagiarism and altruism in assessment scenarios (McAdam 2017). A student may share their work with their classmates for altruistic or egoistic reasons, allowing the classmates to enhance or expand it before submitting it as their own. In these types of cases, sharing work is not beneficial or supported by the institution because the work may create unfair advantages for certain students, and prevent educators from making accurate assessments of student accomplishment. Sharing among students should be conducted in such a way that all students have the opportunity to reap the benefits and the institution can monitor what is being shared. Appropriate ORP and OER policy development tailored to the institution would increase transparency and avoid plagiarism issues by educating users on copyright policies and intellectual property rights.

In contrast to the attitudes of students, educators did not mention plagiarism concerns in any of their comments. Educators seemed to be more concerned about financial implications of sharing their work as OERs, which may be because their expertise is crucial to their job security and livelihood. Their comments suggested that they were concerned that OERs would devalue teaching materials. For example, one educator commented, "One concern: In this economistic world, OERs could be a way to reduce the jobs of educators", and another noted, "Giving educators resources... makes education better, [but] sounds like part of the slippery slope we're on toward devaluing the original intellectual work involved in teaching well... It sounds like something that an administrator is going to use as justification for not investing in actual teaching."

Educators confirmed that they would require to be acknowledged as the original author, and that they did not want their materials used for commercial purposes, which may be their way of protecting their financial livelihood. Unfortunately, the questionnaire did not specify how respondents defined "commercial purposes", and educators may have interpreted the term in 
different ways. Educators' concerns may be assuaged by increasing awareness around Creative Commons licensing, where educators have the opportunity to clarify the definition of "commercial purposes" within the license. Educators who are aware of the option to restrict commercial reuse of their materials via the license may be less concerned about financial losses from contribution.

\section{Conclusion}

Survey responses found that both educators and students do not generally upload their educational materials for others to utilize, although students have done so more than educators. The ratio of creation to usage was low, which may be an indicator of poor OER adoption. Many students and educators were willing to upload their materials for altruistic reasons, if encouraged by institutional support, but have not done so in the past. Student contributions were limited by lack of awareness and lack of quality concerns, whereas educator contributions were limited by copyrighting and financial concerns. These results indicate that an OER initiative in aquaculture higher education could utilize the volunteer contributions to lower the budget requirements and enhance sustainability of the initiative with changes to institutional policies and procedures that support contribution and protect intellectual property rights.

Higher educational institutions could become champions for these proposed repositories by revising their copyright policies and creating incentives for educators unmotivated by altruistic inclinations or limited by other barriers. Supplementary administration and technology costs that may not be entirely supported through volunteer contributions or free software could be covered by institutions or relevant government funding bodies; however, removing barriers to volunteer contribution and implementing OPRs is the first step to enabling a sustainable volunteer-based OER repository for the global aquaculture community.

\section{Compliance with ethical standards}

Conflict of interest Both authors have received funding from the European Union's Horizon 2020 research and innovation program under Grant Agreement No. 728030. This output reflects the views of the author(s) and the European Union cannot be held responsible for any use, which may be made of the information contained therein.

Ethical approval This article does not contain any studies with animals performed by any of the authors.

Open Access This article is distributed under the terms of the Creative Commons Attribution 4.0 International License (http://creativecommons.org/licenses/by/4.0/), which permits unrestricted use, distribution, and reproduction in any medium, provided you give appropriate credit to the original author(s) and the source, provide a link to the Creative Commons license, and indicate if changes were made.

\section{References}

Atkins D, Brown J, Hammond A. (2007) A review of the open educational recourse (OER) movement: achievements, challenges, and new opportunities. [online] San Francisco: Report to The William and Flora Hewlett Foundation. Available at: http://www.hewlett.org/wp-content/uploads/2016/08 /ReviewoftheOERMovement.pdf [Accessed 6 May 2017]

Butcher N, Hoosen S (2012) Exploring the business case for OER. In: World OER Congress. [online] Vancouver: Commonwealth of Learning and UNESCO. Available at: http://oasis.col.org/handle/11599/57 [Accessed 7 May 2017] 
Callegaro M, Manfreda K, Vehovar V (2015) Web survey methodology. SAGE Publications, London ISBN: 978-0-85702-860-0

Camilleri A, Ferrari L, Haywood J, Maina M, Perez-Mateo M, Soldado R, Nouira C, Sangra A, Tannhauser A (2012) Open learning recognition: taking open educational resources a step further. [online] Brussels: European Foundataion for Quality in e-Learning (BE). Available at: https:/oerknowledgecloud. org/sites/oerknowledgecloud.org/files/Open-Learning-Recognition.pdf [Accessed 8 May 2017]

Carson S (2006) 2005 program evaluation findings report - MIT OpenCourseWare. [online] Boston: Massachusetts Institute of Technology Available at: https:/ocw.mit.edu/ans7870/global/05_Prog_Eval_ Report_Final.pdf [Accessed 17 May 2017]

Chapman B (2010) How long does it take to create learning? [online] available at: http://www.chapmanalliance. com/howlong/ \{accessed 30 July 2017]

Collins D (2003) Pretesting survey instruments: an overview of cognitive methods. Qual Life Res 12(3):229238. https://doi.org/10.1023/A:1023254226592

Collins S, Levy P (2013) Guide to the use of open educational resources in K-12 and postsecondary education. [online] Vermonth: Software \& Information Industry Association. Available at: http://archive.siia.net/index. php?option=com_docman\&task=doc_view\&gid=4036\&Itemid=318 [Accessed 17 May 2017]

Dholakia U, King W, Baraniuk R (2006) What makes an open education program sustainable? The case of Connexions. [online] Rice: $O E C D$. Available at: http://www.oecd.org/edu/ceri/36781781.pdf [Accessed 17 May 2017]

Downes S (2007) Models for sustainable open educational resources. [online] Interdisciplinary Journal of Knowledge and Learning Objects, 3(1), pp.29-44. Available at: https://www.oecd.org/edu/ceri/36781698. pdf [Accessed 8 May 2017]

Ehlers U (2011) Extending the territory: from open educational resource to open educational practices. JOFDL 15(2):1-10

EU (2017) The European Asian aquaculture technology and innovation platform (EURASTiP). European Union Horizon 2020 Research and Innovation Programme

Guo R, Dobson T, Petrina S (2008) Digital natives, digital immigrants: an analysis of age and Ict competency in teacher education. J Educ Comput Res 38(3):235-254. https://doi.org/10.2190/EC.38.3.a

Herrera S (2010) Open educational resources: how can open education programs be sustainable? Access to Knowledge, 2(1), pp. 1-11. Available at: file://Users/alexandrapounds/Downloads/425-1-1527-1-1020120713.pdf [Accessed 17 May 2017]

Kanwar A, Kodhandaraman B, Umar A (2010) Towards sustainable open education resources: a perspective from the global south. Am J Dist Educ 24:65-80. https://doi.org/10.1080/08923641003696588

Kawachi P (2014) Quality assurance guidelines for open educational resources: TIPS framework. [online] New Delhi: CEMCA. Available at: http://oasis.col.org/handle/11599/562 [Accessed 26 May 2017]

Krosnick J (1999) Survey research. Annu Rev Psychol 50:537-367. https://doi.org/10.1146/annurev. psych.50.1.537

Lai K, Hong K (2014) Technology use and learning characteristics of students in higher education: do generational differences exist? Br J Educ Technol 46(4):725-738. https://doi.org/10.1111/bjet.12161

Mercer-Mapstone L, Dvorakova SL, Matthews KE, Abbot S, Cheng B, Felten P, Knorr K, Marquis E, Shammas R, Swaim K (2017) A systematic literature review of students as partners in higher education. International Journal for Students as Partners 1(1). https://doi.org/10.15173/ijsap.v1i1.3119

McAdam B (2017) Interviewed by A. Pounds on 3 August 2017

McKerlich R, Ives C, McGreal R (2013) Measuring use and creation of open educational resources in higher education. The International Review of Research in Open and Distance Learning 14(4):90-102

Pawlowski J, Bick M (2012) Open educational resources. Wirtschaftsin Informatik 54(4):205-208. https://doi. org/10.1007/s12599-012-0219-3

Pounds A (2017) Open education resources (OER) and aquatic resource management higher education institutions: opportunities, barriers and future perspectives. Dissertation, University of Stirling

Power C (2000) Global trends in education. [online] Int Educ J, 1(3), pp.152-163. Available at: http://iej.cjb.net [Accessed 26 May 2017]

Wenger E (1998) Community of practice.Cambridge: Cambridge University Press

Wiley D (2007) On the sustainability of open educational resource initiatives in higher education. [online] OECD's Centre for Educational Research and Innovation: open educational resources project. Available at: https://www.oecd.org/edu/ceri/38645447.pdf [Accessed May 7 2017]

Publisher's note Springer Nature remains neutral with regard to jurisdictional claims in published maps and institutional affiliations. 